\title{
Racial differences in red cell indices
}

\author{
D ISAACS,* DG ALTMAN, $\dagger$ HB VALMAN* \\ From the Departments of ${ }^{*}$ Paediatrics and + Computing and Statistics, Northwick Park Hospital and Clinical \\ Research Centre, Harrow, Middlesex
}

SUMMARY A high prevalence of iron deficiency was found in apparently healthy Asian immigrant children in Harrow. After excluding children with overtly abnormal red cell indices, Asian and European children had identical haemoglobin values, but Asian children had much lower mean cell volume and mean corpuscular haemoglobin values and higher red blood cell values.

The criteria that define children as normal for inclusion in haematological reference ranges are critical. Viteri et al excluded all children with hookworm in a central American population, and also those with low serum concentrations of iron, folate, and vitamin $B_{12}$, although the authors did not state how their criteria for normal serum concentrations were derived. ${ }^{1}$ Other workers included data from all children attending infant welfare clinics, ${ }^{2}$ or kindergartens, ${ }^{3}$ or used longitudinal data on healthy full term infants. ${ }^{4} \mathrm{We}$ analysed data from supposedly normal children attending child welfare clinics and schools. The data were subdivided and analysed according to age and race.

\section{Subjects and methods}

The subjects were normal healthy children attending infant welfare clinics and schools in the Harrow area between May 1980 and June 1981. They were aged between 6 months and 6 years of age: children with known haematological disorders (one child with thalassaemia trait) and those taking haematinics (two children taking oral iron preparations) were excluded from the study. Blood was already being taken, with informed parental consent, for a study on pertussis antibodies (to be published elsewhere). When sufficient blood had been obtained by venepuncture $0.3-0.5 \mathrm{ml}$ was placed in a paediatric sequestrene tube and agitated gently. Specimens were analysed on a model S Coulter counter within six hours of venesection.

Initially, if particular results were evidently abnormal (haemoglobin $<10.0 \mathrm{~g} / \mathrm{dl}$ or mean cell volume $<70 \mathrm{fl}$, or both) the child was traced and blood taken

Accepted for publication 29 August 1985 for serum iron concentration, total iron binding capacity (TIBC), and haemoglobin electrophoresis. At a later stage of the study an attempt was made to trace all statistically defined abnormal children (outliers) to perform the same studies, but this was not always possible.

Beta thalassaemia trait was diagnosed when $\mathrm{HbA}_{2}$ concentrations were greater than $3.5 \%$ or when those of $\mathrm{HbF}$ were greater than $2.0 \%$, or both, in the presence of microcytosis and a near normal haemoglobin value. Iron deficiency was diagnosed on the basis of a serum iron concentration below $12 \mu \mathrm{mol} / 1$ $(67 \mu \mathrm{g} / 100 \mathrm{ml})$ and iron binding capacity above 75 $\mu \mathrm{mol} / 1 \quad(4 / 8 \cdot 1 \mu \mathrm{g} / 100 \mathrm{ml}$ ) (our laboratory normal range).

A few children with one or more haematological values well outside the other values - that is, statistical outliers-were excluded from analysis in the $95 \%$ reference ranges. The method used for development of the reference ranges was as described previously for serum immunoglobulin values in childhood. ${ }^{56}$ Briefly, the data were transformed so that the ensuing data values were reasonably normally distributed at all ages. The transformation for which the subsequent values were closest to a normal distribution was found using Shapiro and Wilk's W test. ${ }^{7}$ A polynomial regression model was fitted to the transformed data and another polynomial regression model was fitted to the standard deviations of the residuals from the previous regression. For this purpose the age range was subdivided into eight. The references range was calculated as follows:

$$
f_{1} \text { (age) (SD (1.96)) } f_{2} \text { (age) }
$$

$f_{2}$ and $f_{2}$ are the fitted functions of age derived by the two polynomial regression models. The goodness of fit of the models was carefully assessed. 


\section{Results}

Data were available from 251 children, 189 of whom were of European and 62 of whom were of Asian extraction. Fifteen children with extreme results were excluded from the derivation of reference ranges (Table). Of these 15 children, seven (six Asian, one European) had iron deficiency, three (two Asian, one European) had $\beta$ thalassaemia trait, and five (four Asian, one European) could not be traced. Thus all statistical outliers who could be traced were abnormal. The incidence of confirmed iron deficiency based on our criteria was, therefore, six in 62 or $96.8 / 1000$ Asian children compared with one in 189 or $5 \cdot 3 / 1000$ European children ( $p<0.001$, Fisher's exact test).

After the outliers' results had been excluded haematological data were analysed as previously described $^{5}$ and examined for variability with age, sex, and race. No difference between sexes was found for any variable.

\section{Haemoglobin}

There was a weak but significant age effect $(p=0.025)$ corresponding to an increase in haemoglobin concentration of $0.06 \mathrm{~g} / \mathrm{dl}$ per year. Fig. 1 shows the results. The mean haemoglobin concentration can be calculated as $(12.11+0.00562 \mathrm{~A}) \mathrm{g} / \mathrm{dl}$ where $\mathrm{A}=$ age in months, and the standard deviation (SD) is $0.76 \mathrm{~g} / \mathrm{dl}$. There was no significant difference between the mean haemoglobin for European children and Asian children: mean haemoglobin values were $12.30(0.80) \mathrm{g} / \mathrm{dl}$ and $12.39(0.82) \mathrm{g} / \mathrm{dl}$, respectively $(\mathrm{t}=1 \cdot 57, \mathrm{p}=0 \cdot 1)$.

\section{Red blood cell count}

There was a significant difference between the mean red blood count for European children $(4.69(0.32) \times$ $\left.10^{12} / 1\right)$ and Asian children $\left(5.00(0.36) \times 10^{12} / 1\right) ; \mathrm{t}=$ $5.87, p<0.0001$. The $95 \%$ reference ranges were

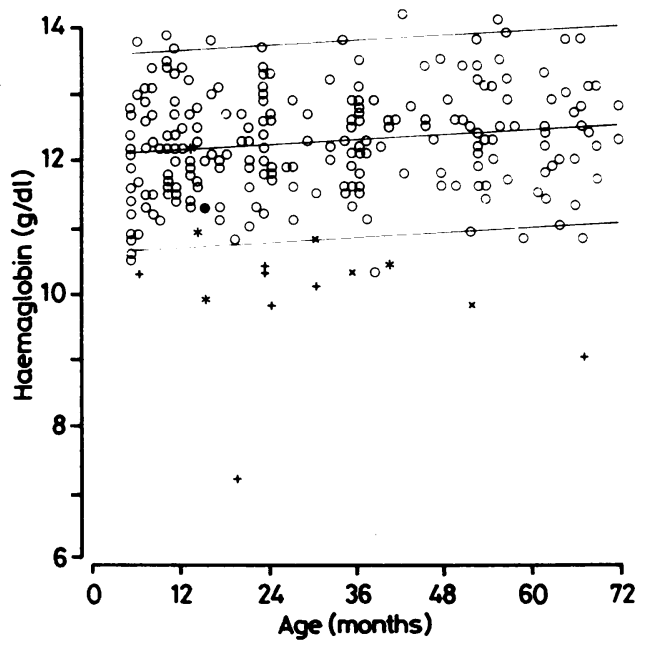

Fig. 1 Reference range for haemoglobin $(\mathrm{Hb})$ for European and Asian children. $\mathrm{O}=$ Normal children; * =Iron deficient; $x=\beta$-thalassaemia trait $;+=$ Outlier lost to follow up; Mean \pm 2 standard deviations is shown.

(4.05 to $\left.5.33 \times 10^{12} / 1\right)$ for European children and (4.36 to $\left.5.64 \times 10^{12} / 1\right)$ for Asian children. There was no significant age effect $(\mathrm{p}=0.8)$.

\section{Packed cell volume}

Packed cell volume did not change with age. Analysing European and Asian children together, the mean packed cell volume was $37.52(2.26) \%$. When considered separately the mean packed cell volume for Europeans was $37.37(2.23) \%$ and for Asians $38.01(2.34) \% ; t=1.92, p=0.06$. The $95 \%$ reference range for Europeans and Asians combined at any age $\dot{0}$ from 6 months to 6 years was $33 \cdot 09-41 \cdot 95 \%$.

Table Characteristics of children with abnormal haematological values

\begin{tabular}{|c|c|c|c|c|c|c|c|}
\hline $\begin{array}{l}\text { Age } \\
\text { (year) }\end{array}$ & Sex & Race & $\begin{array}{l}\text { Red blood } \\
\text { cells } \\
\left(\times 10^{12} / l\right)\end{array}$ & $\begin{array}{l}\text { Haemoglobin } \\
(g / d l)\end{array}$ & $\begin{array}{l}\text { Packed cell } \\
\text { volume }(\%)\end{array}$ & $\begin{array}{l}\text { Mean cell } \\
\text { volume }(f)\end{array}$ & $\begin{array}{l}\text { Mean } \\
\text { corpuscular } \\
\text { haemoglobin } \\
\text { (pg) }\end{array}$ \\
\hline $\begin{array}{l}2 y 0 \mathrm{~m} \\
2 y 0 \mathrm{~m} \\
2 y 7 \mathrm{~m} \\
2 y \mathrm{~lm} \\
\text { ly } 8 \mathrm{~m} \\
0 y 7 \mathrm{~m} \\
5 y 7 \mathrm{~m} \\
\text { 3y } 0 \mathrm{~m} \\
4 y 4 \mathrm{~m} \\
2 y 7 \mathrm{~m} \\
\text { ly } 4 \mathrm{~m} \\
\text { ly } 3 \mathrm{~m} \\
\text { ly } 4 \mathrm{~m} \\
\text { 3y } 5 \mathrm{~m} \\
\text { ly } 2 \mathrm{~m}\end{array}$ & $\begin{array}{l}\mathbf{M} \\
\mathbf{F} \\
\mathbf{M} \\
\mathbf{F} \\
\mathbf{F} \\
\mathbf{F} \\
\mathbf{M} \\
\mathbf{F} \\
\mathbf{F} \\
\mathbf{M} \\
\mathbf{F} \\
\mathbf{M} \\
\mathbf{M} \\
\mathbf{M} \\
\mathbf{F}\end{array}$ & $\begin{array}{l}\text { Asian } \\
\text { Asian } \\
\text { Asian } \\
\text { Asian } \\
\text { Asian } \\
\text { Asian } \\
\text { European } \\
\text { Asian } \\
\text { European } \\
\text { Asian } \\
\text { Asian } \\
\text { Asian } \\
\text { Asian } \\
\text { Asian } \\
\text { European }\end{array}$ & $\begin{array}{l}5 \cdot 70 \\
5 \cdot 19 \\
5 \cdot 40 \\
5 \cdot 74 \\
4 \cdot 56 \\
4.99 \\
4 \cdot 64 \\
5 \cdot 89 \\
5 \cdot 41 \\
6 \cdot 42 \\
5 \cdot 22 \\
5 \cdot 85 \\
5 \cdot 09 \\
4 \cdot 87 \\
6 \cdot 24\end{array}$ & $\begin{array}{r}10 \cdot 3 \\
10 \cdot 4 \\
10 \cdot 1 \\
9 \cdot 8 \\
7 \cdot 2 \\
10 \cdot 3 \\
9 \cdot 0 \\
10 \cdot 3 \\
9 \cdot 8 \\
10 \cdot 8 \\
9 \cdot 8 \\
10 \cdot 9 \\
9.9 \\
10 \cdot 4 \\
12 \cdot 2\end{array}$ & $\begin{array}{l}35 \cdot 9 \\
35 \cdot 8 \\
35 \cdot 6 \\
36 \cdot 2 \\
26 \cdot 0 \\
32 \cdot 9 \\
28 \cdot 8 \\
35 \cdot 9 \\
33 \cdot 5 \\
34 \cdot 8 \\
34 \cdot 9 \\
37 \cdot 0 \\
34 \cdot 1 \\
33 \cdot 1 \\
41 \cdot 1\end{array}$ & $\begin{array}{l}63 \\
69 \\
66 \\
63 \\
57 \\
66 \\
62 \\
61 \\
62 \\
54 \\
67 \\
63 \\
67 \\
68 \\
66\end{array}$ & $\begin{array}{l}18 \cdot 1 \\
20 \cdot 0 \\
18 \cdot 7 \\
17 \cdot 1 \\
15 \cdot 7 \\
20 \cdot 6 \\
19 \cdot 4 \\
17 \cdot 4 \\
18 \cdot 1 \\
16 \cdot 8 \\
18 \cdot 3 \\
18.6 \\
19.4 \\
21.4 \\
19.5\end{array}$ \\
\hline
\end{tabular}

ND $=$ Not done 


\section{Mean corpuscular volume}

Mean corpuscular volume increased significantly with age. It also differed significantly by race: the mean corpuscular volume for Asian children of 76.02 (3.26)fl was far lower than that for European children, $79.70(3.14)$ fl $(t=7.16 p<0.0001)$. Separate equations were, therefore, derived for the mean corpuscular volume for Asian and European children using a common regression slope for the two groups: Asian children, mean corpuscular volume $=(75 \cdot 11+$ 0.033A) fl; European children, mean corpuscular volume $=(78.66+0.033 \mathrm{~A}) \mathrm{fl}$; Asian and European children, standard deviation $=3 \cdot 10 \mathrm{fl}(\mathrm{A}=$ age in months). Figs. 2 and 3 show the reference ranges.

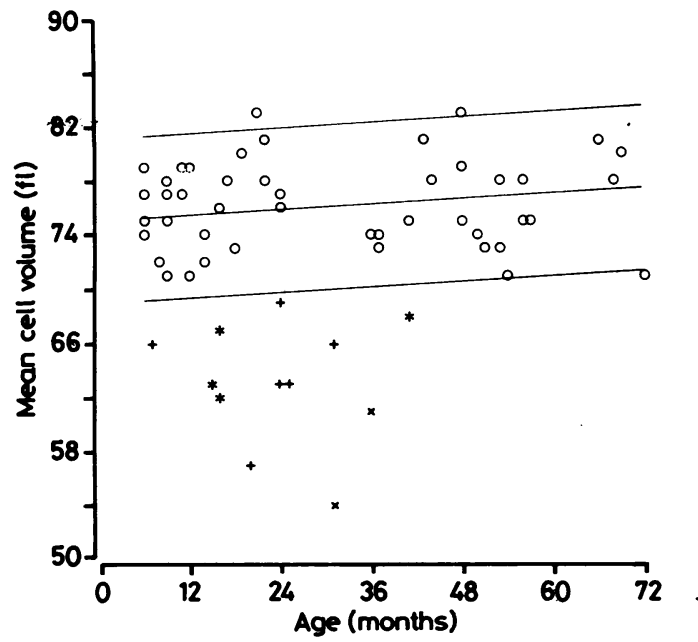

Fig. 2 Reference range for mean corpuscular volume for Asian children. $\bigcirc=$ Normal children; ${ }^{*}=$ Iron deficient; $\times=\beta$-thalassaemia trait $+=$ Outlier lost to follow up; Mean \pm 2 standard deviations is shown.

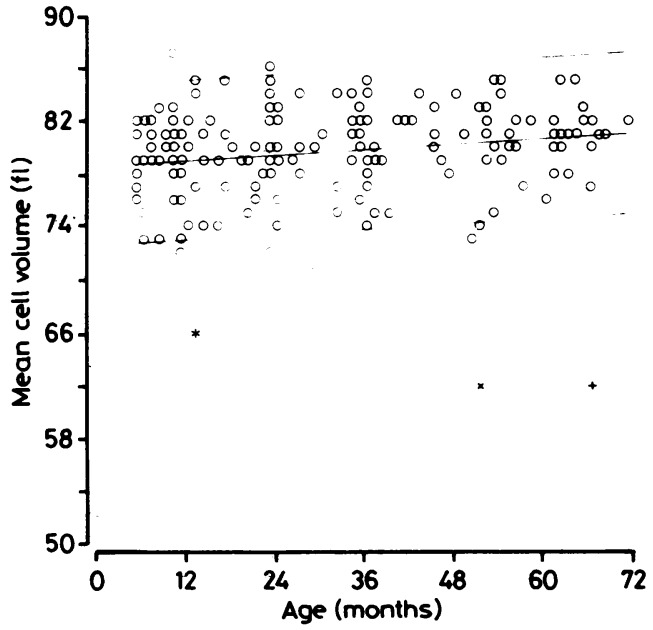

Fig. 3 Reference range for mean corpuscular volume for European children. $\bigcirc=$ Normal children; ${ }^{*}=$ Iron deficient; $\times=\beta$-thalassaemia trait $;+=$ Outlier lost to follow up; Mean \pm 2 standard deviations is shown.

\section{Mean corpuscular haemoglobin}

Mean corpuscular haemoglobin, like mean corpuscular volume, increased with age and also showed a significant difference between European and Asian children (mean corpuscular haemoglobin $=26 \cdot 10$ $(1.29)$ and $24.87(1.59) \mathrm{pg}$, respectively; $\mathrm{t}=5.65, \mathrm{p}<$ $0.0001)$. The models derived, analysing separately for race, were as follows:

Asian children, mean corpuscular haemoglobin $=$ $(24.42+0.015 \mathrm{~A}) \mathrm{pg}$. European children, mean corpuscular haemoglobin $=(25.62+0.015 \mathrm{~A}) \mathrm{pg}$; Asian and European children, standard deviation $=1.32 \mathrm{pg}$ ( $\mathrm{A}=$ age in months). Figs. 4 and 5 show the reference ranges.

\begin{tabular}{|c|c|c|c|c|}
\hline $\begin{array}{l}\text { Mean corpuscular } \\
\text { haemoglobin } \\
\text { concentration ( } \mathrm{g} / \mathrm{dl})\end{array}$ & $\begin{array}{l}\text { Serum iron } \\
\text { concentrations } \\
(\mu \mathrm{mol} / \mathrm{l})\end{array}$ & $\begin{array}{l}\text { Total iron binding } \\
\text { capacity } \\
(\mu \mathrm{mol} / \mathrm{l})\end{array}$ & Haemoglobin electrophoresis & Diagnosis \\
\hline $\begin{array}{l}28 \cdot 7 \\
29 \cdot 1 \\
28 \cdot 4 \\
27 \cdot 1 \\
27 \cdot 6 \\
31 \cdot 3 \\
31 \cdot 3 \\
28 \cdot 7 \\
29 \cdot 2 \\
31 \cdot 0 \\
28 \cdot 0 \\
29 \cdot 5 \\
29 \cdot 0 \\
31 \cdot 4 \\
29 \cdot 6\end{array}$ & $\begin{array}{r}5 \\
8 \\
6 \\
4 \\
10 \\
5 \\
3 \\
24 \\
14 \\
34 \\
\text { ND } \\
\text { ND } \\
\text { ND } \\
\text { ND } \\
\text { ND }\end{array}$ & $\begin{array}{r}114 \\
90 \\
96 \\
99 \\
93 \\
88 \\
74 \\
42 \\
35 \\
60 \\
\text { ND } \\
\text { ND } \\
\text { ND } \\
\text { ND } \\
\text { ND }\end{array}$ & $\begin{array}{l}\left.\begin{array}{l}\text { Normal } \\
\text { Normal } \\
\text { Normal } \\
\text { Normal } \\
\text { Normal } \\
\text { Normal } \\
\text { Normal } \\
A_{2} 4 \cdot 6 \% \text { F } 1.9 \% \\
A_{2} 5 \cdot 9 \% \text { F } 2 \cdot 4 \% \\
A_{2} 5 \cdot 5 \% \text { F } 2 \cdot 6 \% \\
\text { ND } \\
\text { ND } \\
\text { ND } \\
\text { ND } \\
\text { ND }\end{array}\right\}\end{array}$ & $\begin{array}{l}\text { Iron deficient } \\
\beta \text {-thalassaemia trait }\end{array}$ \\
\hline
\end{tabular}




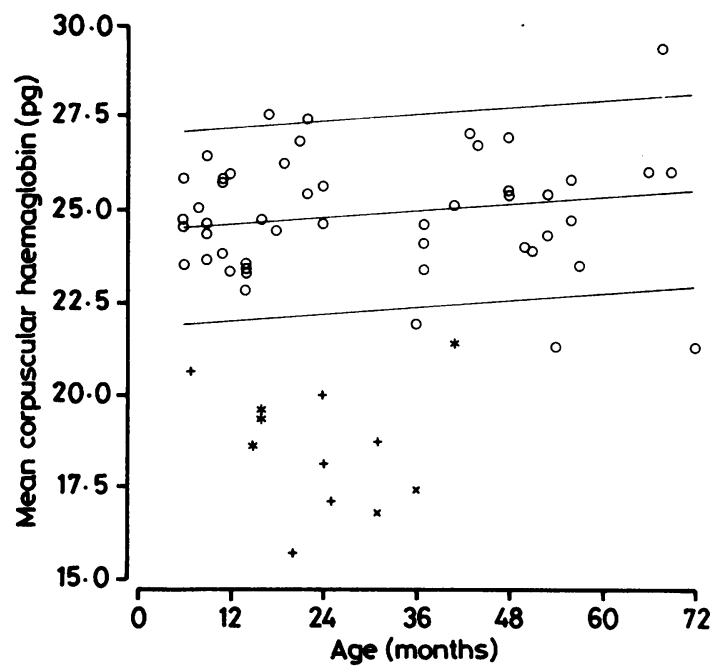

Fig. 4 Reference range for mean corpuscular haemoglobin for Asian children. $\bigcirc=$ Normal children; ${ }^{*}=$ Iron deficient; $x=\beta$-thalassaemia trait $;+=$ Outlier lost to follow up; Mean \pm 2 standard deviations is shown.

\section{Mean corpuscular haemoglobin concentration}

There was no apparent age effect, either in mean values or variability, of mean corpuscular haemoglobin concentration, so the best model was mean corpuscular haemoglobin concentration of $32.77(1.09)$ $\mathrm{g} / \mathrm{dl}, 95 \%$ reference range, $30.63-34.91 \mathrm{~g} / \mathrm{dl}$. There was no difference between mean corpuscular haemoglobin concentration for Europeans and Asians

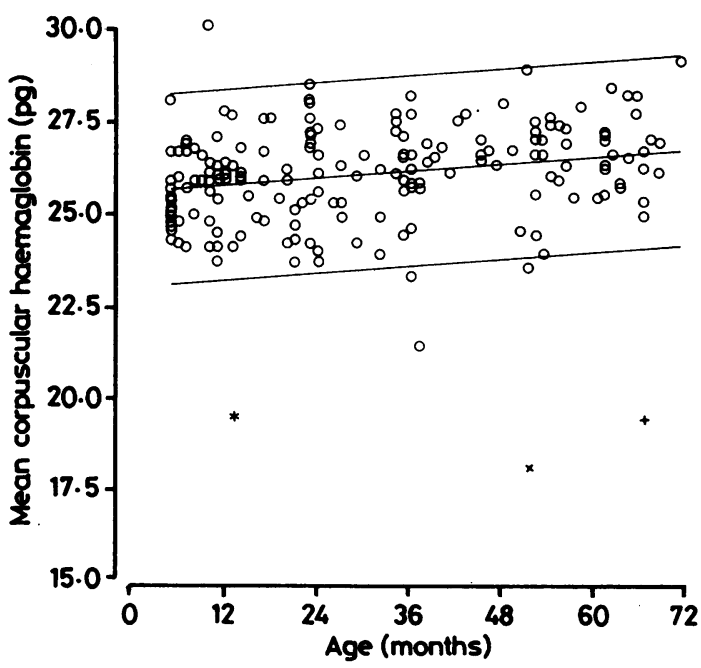

Fig. 5 Reference range for mean corpuscular haemoglobin for European children. $\bigcirc=$ Normal children; ${ }^{*}=$ Iron deficient; $\times=\beta$-thalassaemia trait $;+=$ Outlier lost to follow up; Mean \pm 2 standard deviations is shown.
$($ mean $(\mathrm{SD}),=32.77(0.96) \mathrm{g} / \mathrm{dl}$ and $32.81(1.51) \mathrm{g} / \mathrm{dl}$, respectively; $\mathrm{t}=0 \cdot 16, \mathrm{p}=0.8)$.

\section{Discussion}

A high rate of overt iron deficiency in Asian immigrant children has been recognised for some time and is related to early weaning ${ }^{8}$ and weaning on to diets deficient in iron. ${ }^{910}$ This may partly be related to social class as iron deficiency and iron deficiency anae- . mia are considerably more prevalent in low income families. ${ }^{1112}$ Not only did we find that six of the 62 Asian children studied had abnormal red cell indices and low serum iron concentrations, but four of the five children with abnormal red cell indices who were $₫$ lost to follow up were also Asian. Thus in this small survey at least $9.7 \%$ of Asian children were frankly $\vec{\circ}$ iron deficient, and $3.4 \%$ had $\beta$-thalassaemia trait. The Asian children in Harrow tend, however, to come from families of higher socioeconomic class than those in Wolverhampton, ${ }^{8}$ Blackburn, ${ }^{9}$ and Tower Hamlets, ${ }^{10}$ and the prevalence of iron deficiency in Asian children in Harrow is thus surprisingly high. Unfortunately, we did not obtain a dietary history on the children studied.

Haemoglobin values increased with age, but there was virtually no difference between the mean haemoglobin concentrations of European and Asian children at any given age. Packed cell volume and mean corpuscular haemoglobin concentration were also very similar in European and Asian children. Even allowing for age, however, mean cell volume and mean corpuscular haemoglobin were significantly lower in Asian children than in Europeans at the $\mathrm{p}<$ 0.0001 level, and red blood cells significantly higher, suggesting an effect that was certainly not arbitary. There would seem to be two possible explanations for these racial differences. The first is that there was a 3 high prevalence of mild subclinical iron deficiency in the Asian children, causing an effect on the most sensitive red cell indices, red blood cells, mean cell volume, and mean corpuscular haemoglobin, but not on overall measurements of haemoglobin. A second possibility is that there was some inherent difference in the morphology of the red cell between Asian and European children. We did not routinely measure serum iron concentrations or any other variable of iron balance and are unable to say if either of these suggestions is valid. The high prevalence of overt iron deficiency in a middle class Asian immigrant population, however, particularly evident in children between 18 and 36 months old (Table), suggests that the diet of many Asian immigrant children, regardless of social class, may be deficient in iron. Further studies are necessary to clarify this issue.

The Medical Research Council generously funded this study. 


\section{References}

${ }^{1}$ Viteri FE, de Tuna V, Guzman MA. Normal haematological values in the central American population. Br J Haematol 1972;23: 189-204.

${ }^{2}$ Koerper MA, Meutzer WC, Brecher G, Dallman PR. Developmental changes in red blood cell volume: implication in screening infants and children for iron deficiency and thalassaemia trait. J Pediatr 1976;89:580-3.

${ }^{3}$ Marner T. Haemoglobin, erythrocytes and serum iron values in normal children 3-6 years of age. Acta Paediatr Scand 1969;58:363-8.

${ }^{4}$ Matoth Y, Zaizov R, Varsano I. Postnatal changes in some red cell parameters. Acta Paediatr Scand 1971;60:317-23.

${ }^{5}$ Isaacs D, Altman DG, Tidmarsh CE, Valman HB, Webster ADB. Serum immunoglobulin levels in pre-school children measured by laser nephelometry: reference ranges for IgG, IgA and IgM. J Clin Pathol 1983;36:1193-6.

${ }^{6}$ Altman DG. Statistics and ethics in medical research. Collecting and screening data. $\mathrm{Br}$ Med J 1980:1399-401.
${ }^{7}$ Royston JP. An extension of Shapiro and Wilk's W test for normality to large samples. Applied Statistics 1982;31:115-24.

${ }^{8}$ Evans N, Walpole IR, Qureshi MU, Memon MH, Everley Jones HW. Lack of breast feeding and early weaning in infants of Asian immigrants to Wolverhampton. Arch Dis Child 1976;51:608-12.

9 Jivani SKM. The practice of infant feeding among Asian immigrants. Arch Dis Child 1978;53:69-73.

${ }^{10}$ Harris RJ, Armstrong D, Ali R, Loynes A. Nutritional survey of Bangladeshi children aged under 5 years in the London borough of Tower Hamlets. Arch Dis Child 1983;58:428-32.

${ }^{11}$ Picciano MF, Deering RH. The influence of feeding regimen on iron status during infancy. Am J Clin Nutr 1980;33:746-53.

12 Bowering J, Lowenberg RL, Morrison MA, et al. Infant feeding practices in east Harlem. J Am Diet Assoc 1978;72:148-55.

Requests for reprints to: Dr D Isaacs, Department of Paediatrics, John Radcliffe Hospital, Headington, Oxford OX3 9DU, England. 
Surgical Pathology of Bone Marrow. Core Biopsy Diagnosis. Major Problems in Pathology. Vol 17. B Wittels. (Pp 162; £35.50.) WB Saunders. 1985.

The interpretation of bone marrow pathology continues to present difficulties both for pathologists and haematologists, who for different reasons tend to feel inadequate for the task. This book aims to provide the kind of guidance which both require. Emphasis has been placed on key issues; comprehensiveness has not been attempted, although the scope is quite wide ranging. Histopathologists, in particular, will appreciate the option for standard histological methods. Specialised techniques such as plastic embedding and ultrastructure are thought to be too laborious, too restrictive, and, with some notable exceptions, unnecessary for general purposes. The sections on myloproliferative disorders and metastatic tumours are probably the best. The approach to lymphoid disorders is less avant garde; little mention is made, for example, of $\mathrm{T}$ cell neoplasia. A few eyebrows will be raised by the assertions that histiocytosis $\mathrm{X}$ is neoplastic and that the so called malignant histiocytosis complicating acute leukaemia is benign and reactive. Nevertheless, pathologists and haematologists will unquestionably benefit from reading this stimulating, if at times rather controversial, monograph.

FD LEE

\section{Some new titles}

The receipt of books is acknowledged, and this listing must be regarded as sufficient return for the courtesy of the sender. Books that appear to be of particular interest will be reviewed as space permits.

A Practical Approach to Infectious Diseases. Ed RE Reese, RG Doublas. (Pp 798; soft cover $£ 30 \cdot 65$.) Churchill Livingstone. 1985. ISBN 0316737127.

Transformation Assay of Established Cell Lines; Mechanisms and Application. IARC Scientific Publications no 67. Ed T Kakunaga, H Yamasaki. (Pp 225; £20.) Oxford University Press. 1986.
Growth factors in biology and medicine. Ciba Foundation Symposium 116. (Pp 283; £27.95) Pitman. 1985. ISBN 0272798185.

Biochemistry of Macrophages. Ciba Foundation Symposium 118. (Pp 256; £27.95.) Pitman. 1985. ISBN 0272798323.

Prenatal and Perinatal Infections; report on a WHO meeting. EURO reports and studies no 93. (Pp 147; Sw fr 12.) World Health Organisation. 1985. ISBN 9289012595.

Modern Cell Biology. Vol 4. Series ed Birgit H Satir. Modern Cell Biology Series. (Pp 240 ; f28.) Alan $R$ Liss Inc. 1985. ISBN 0-8451-3303-9.

\section{ASSOCIATION OF CLINICAL PATHOLOGISTS}

\section{JUNIOR MEMBERSHIP}

Junior membership of the Association is available to all trainees in pathology for up to six years after the start of training. The annual subscription is $£ 15$ and may be claimed against tax. All junior members receive copies of the Journal of Clinical Pathology. Other benefits include membership of the Junior Members' Group and a regular junior members' newsletter; the ACP Newsletter and all other documents regularly sent to full members including the postgraduate education programme.

Junior membership normally leads to full membership of the Association, which represents medical pathologists in hospital practice.

Junior membership is not available to trainees overseas and those on short term training schemes in this country. Requests on an individual basis will be considered.

Apply to: Dr PP Anthony, Education Secretary, Postgraduate Medical School, Barrack Road, Exeter EX2 5DW, Devon.
Fourth International Symposium on Morphometry in Morphological diagnosis

\section{Royal Society of Medicine, September 10-12, 1986}

Although covering image analysis using large systems, many of the contributions will describe the use of small micro based systems suitable for use in a district general hospital. One session will be devoted to flow cytometry. The emphasis throughout will be on clinical applications and clinical usefulness. The programme includes invited expert guest speakers: Bahr (USA); Watson (UK); Ploem (Netherlands); Wied (USA); Aver (Sweden); Baak (Netherlands); Stenkquist (Sweden); and Collan (Finland).

There will also be a wide range of proferred papers and poster demonstrations, particularly on the applications of morphometry to gut, bone, breast, lymphoreticular and urogenital pathology. A pleasing feature of the proferred papers are the contributions correlating structure and function, which is an ideal aim for clinical pathologists.

A limited number of places now remain for attendance at the symposium. These will be allocated on a strictly first come, first served basis.

Further details may be obtained from: Miss Elaine Gill, Gill Medical, 429 Tamworth Road, Long Eaton, Nottingham NG10 3JT, England.

\section{Correction}

The formula on page 105 of the January issue should read:

$f_{1}$ (age) $\pm 1.96 f_{2}$ (age) and not $f_{1}$ (age) (SD 1.96) $\mathrm{f}_{2}$ (age) 